\title{
Quantitative Modeling in the North Sea: Towards a More Confident Assessment of the Critical Risks*
}

\author{
S. Hay ${ }^{1}$, O. Walderhaug ${ }^{1}$, J. Johannesen ${ }^{1}$ and F. Schneider ${ }^{2}$ \\ 1 Statoil, Grenseveien 21, N 4035 Stavanger - Norway \\ 2 Institut français du pétrole, 1 et 4, avenue de Bois-Préau, 92852 Rueil-Malmaison Cedex - France \\ e-mail: stehay@statoil.com - owald@statoil.com - ii@statoil.com - frederic.schneider@ifp.fr \\ *Paper presented at the IFP Session: "Quantitative Basin Evaluation, a Tool for Reducing Exploration Risks" \\ held on 18 June 2001, at Rueil-Malmaison, France
}

\begin{abstract}
Résumé - Modélisation quantitative en mer du Nord : vers une meilleure estimation des risques — La modélisation quantitative est devenue une étape classique de l'analyse des risques, à la fois pour l'analyse des systèmes pétroliers et pour la prédiction de la qualité des réservoirs. Dans cet article, elle est associée à l'évaluation prospective en mer du Nord norvégienne et dans la zone de Haltenbanken.

À ce jour, la mer du Nord norvégienne et certaines parties de la zone de Haltenbanken peuvent être considérées matures. En conséquence, les analyses quantitatives portent essentiellement sur des prospects marginaux hors des zones d'alimentation connues, des prospects satellites dans et autour de gisements connus, et des prospects profonds, souvent sous hautes pressions et hautes températures (HP/HT).

La compréhension des chemins de migration éloignés des zones d'alimentation connues est une clé du succès. À proximité des gisements connus, le rapport gaz/huile (GOR) constitue un facteur de risque. Dans les réservoirs HP/HT, la qualité de ces derniers et la tenue des couvertures sont les facteurs les plus importants. L'application de modèles quantitatifs dans ces environnements permet de mettre en œuvre une méthodologie cohérente d'évaluation, de tester les conséquences des incertitudes géologiques, et d'améliorer la confiance.

Dans cet article, nous illustrons tout d'abord l'utilisation de la modélisation de la migration 3D afin de comprendre les chemins de migration proches des gisements connus et éloignés des zones sources connues. Puis, nous présentons notre expérience pour reproduire les GOR observés avec l'utilisation des modèles compositionnels 2D. Enfin, nous montrons comment nous modélisons l'évolution de la porosité dans des zones HP/HT et l'influence que la diagenèse du quartz, contrôlée par la température, a sur les fuites dans les couvertures et l'évolution des pressions. Ces exemples montrent comment des outils de modélisation quantitative et de nouvelles connaissances sur les processus fondamentaux sont utilisés et développés à ce jour en mer du Nord et dans la zone de Haltenbanken.
\end{abstract}

Abstract - Quantitative Modeling in the North Sea: Towards a More Confident Assessment of the Critical Risks - Quantitative modeling has become a standard part of probability assessment, for both hydrocarbon systems analysis and reservoir quality prediction, undertaken in association with prospectivity evaluation in the Norwegian North Sea and Haltenbanken areas.

Presently, the Norwegian North Sea and parts of Haltenbanken can be classified as mature basins. As such, quantitative assessment is focussed towards assessment of prospects lying on basin margins outside 
known kitchen areas; satellite prospect assessment in and around existing infrastructure; and assessment of deep, often high-pressure, high-temperature (HP/HT) prospects in basin centers.

Outside the known kitchen areas, access to a long-distance petroleum migration route is critical for success. In the proximity of existing infrastructure petroleum migration and trapped fluid gas-to-oil ratio (GOR) are often key risks. In deep, HP/HT settings reservoir quality and top-seal integrity are often the most important factors. Application of quantitative models in these environments allows a consistent evaluation methodology, testing of the consequences of geological uncertainty, and an improvement in confidence.

We will illustrate the use of $3 D$ migration modeling to assess migration fairways close to existing infrastructure and outside known kitchens; our experience of matching observed fluid GOR using $2 D$ compositional modeling; and how we model porosity evolution in HP/HT areas and the influence that thermally controlled quartz diagenesis has on overpressure build-up and top-seal leakage. These examples show how quantitative modeling tools and new understanding of fundamental processes are being used and developed today in the North Sea and Halten bank.

\section{INTRODUCTION}

In exploration, we normally work in confidence and probability spaces (Fig. 1). In an ideal world, we would always be well enough informed to be able to decide whether something would or would not happen, and probability would be either 1 or 0 . Under such circumstances we would have a very high level of confidence. Normally our confidence is not so high. When one has low confidence it is difficult to be anything other than uncertain in our estimation of probability, and a mid-range value is appropriate.

To become more confident requires an evaluation. This is why we undertake quantitative modeling, it is to become more confident in our estimation of the probability assigned to the elements of source, reservoir, trap and fluid type, any

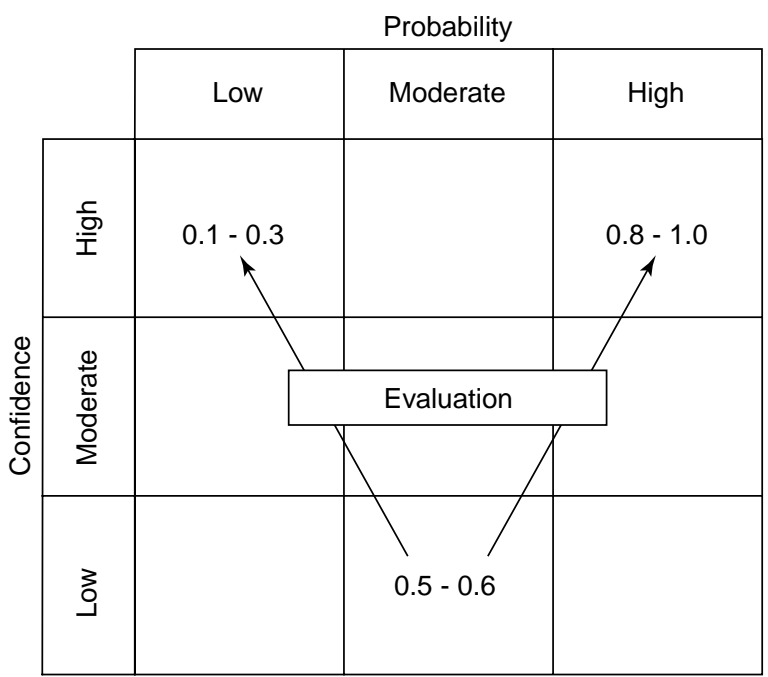

Figure 1

Confidence and probability, the reasons for undertaking quantitative basin evaluation. of which could be a critical risk. Since we assess the value of a prospect or an area, a more confident assessment is better than an uncertain one. However, a probability decrease rather than a probability increase may be the result after evaluation.

Presently in the North Sea and Halten bank areas we use quantitative basin modeling in three main evaluation areas.

Firstly, on prospects that lie outside the known kitchen areas where access to a long-distance migration route is essential, and often a critical element. Secondly, we have satellite prospects around existing infrastructure. Here petroleum migration is again a critical element, with fluid GOR (gas-to-oil ratio) composition being secondary. Thirdly, we have deep, high-temperature and often high-pressure targets in the deeper parts of the basin. These are now being explored later in the basin exploration life cycle. Here a critical risk is often reservoir quality with trap leakage being a secondary risk when high pressure is present.

We will, with the use of case examples, illustrate how quantitative basin modeling is being used by Statoil to assess these critical elements.

\section{PETROLEUM MIGRATION TO THE STATFJORD FIELD}

The Statfjord field (Roberts et al., 1987) lies in the Tampen spur area of the North Viking graben. Statfjord is the largest oil field in the North Sea with close to 4 Gbbl having been produced to date from Lower, Middle and Upper Jurassic reservoir units.

In assessing remaining prospectivity around the Statfjord field, petroleum migration appears as one of the key risks. While the discovered oils were sourced from the Upper Jurassic Draupne formation, both the known fields and surrounding prospects lie outside kitchen areas. The transformation ratio of the Draupne formation is superimposed upon the Base Cretaceous structure showing four major kitchens which could charge this regional high: the Viking graben, the 


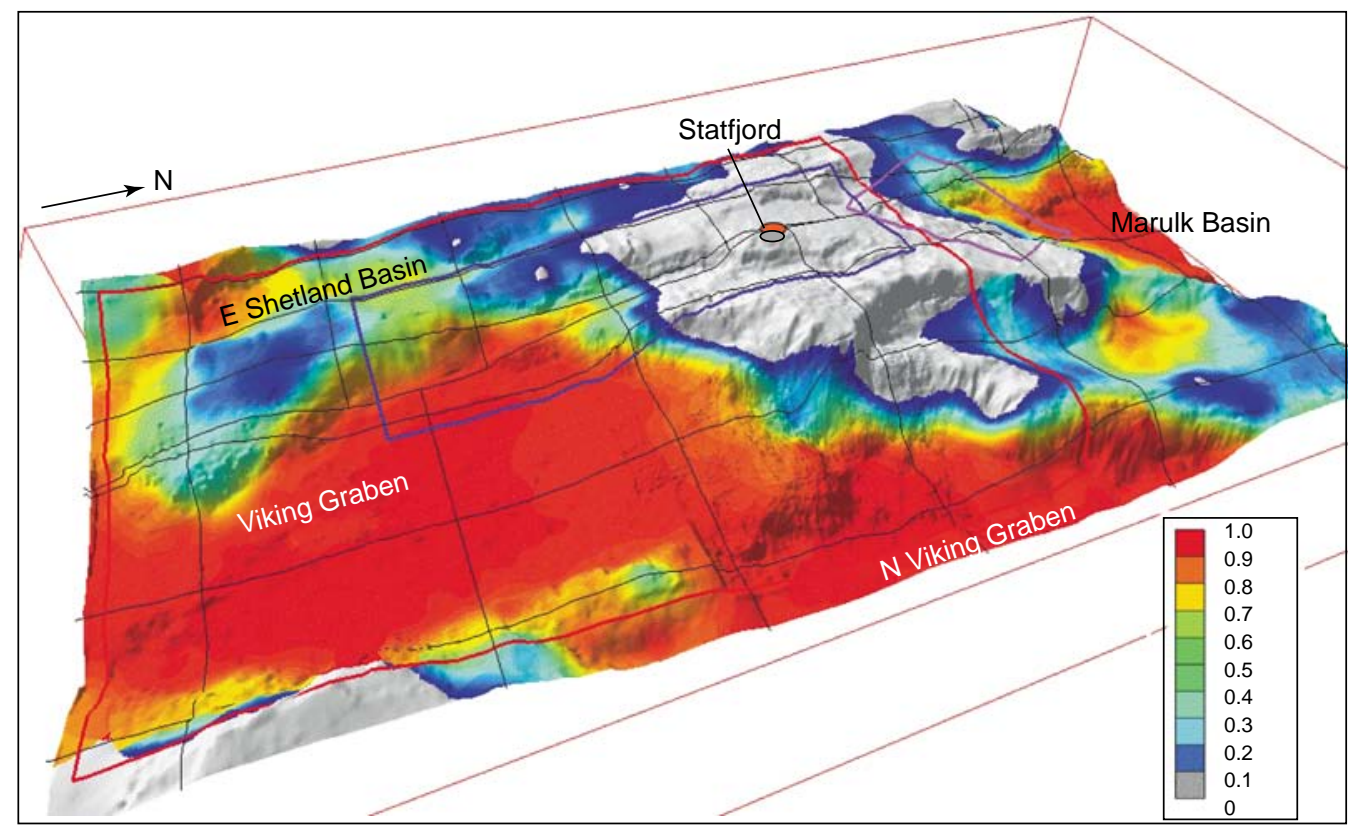

Figure 2

Kitchens of the Statfjord field. The map shows Base Cretaceous depth with the present-day transformation ratio superimposed. Scale from transformation ratio: 0-1.0. Also shown are the locations of the 3D models undertaken.

North Viking graben, the Marulk basin and the East Shetland basin (Fig. 2).

This evaluation set out to establish how the hydrocarbons reached the reservoirs in this area, thereby identifying the main fairways for petroleum migration and allowing the remaining prospects to be assessed accordingly.

A large Temis 3D model (Schneider et al., 2000; Schneider and Wolf, 2000) was built using merged 3D seismic data sets. Several smaller blocks were then extracted and upscaled for further study. The results of two of these blocks focussed towards understanding the migration of petroleum into the Statfjord field Brent group and Statfjord reservoirs from the Viking graben and the East Shetland basin will be summarized here. A full description of the 3D model, model calibration, simulation results, and collaborating data can be found in Johannesen et al. (2000; accepted).

Figure 3 illustrates the present-day structure of the Top Brent group with the color representing simulated petroleum saturation. Red represents high saturation, blue low saturation and grey no saturation. Viewing consecutive time step histories from the simulation allows the development of the petroleum system to be visualized. We are interested in the development of the migration system in order to identify areas that do or do not lie on petroleum migration routes.

The Brent group of the Alwyn North to the Statfjord fault block develops as a major fill-spill system from the Viking graben, with migration being focussed westwards from the basin through the area of the Hild discovery before migrating northwards towards Alwyn North and eventually the Brent field. The petroleum saturations show the fill-spill chain with high saturations in structural closures and low saturations along migration routes from the source kitchen synclines and along spill routes between structures.

It is possible to see a petroleum contribution from the East Shetland basin towards the Brent field in addition to the contribution from the Viking graben. The Statfjord field itself relies on spill from the Brent field to the south. Similarly, the Statfjord Øst field is charged via spill from the Statfjord field before spilling further into the Tordis field and then into the Gullfaks field, which also receives petroleum via a spill-fill system developed through the Rimflaks field.

The important message for prospectivity evaluation is that the petroleum migration fairway at the Brent group level in the Statfjord region is restricted only to the crestal parts of the tilted fault block system. Areas outside this focussed fill-spill route do not receive a petroleum charge. This is a typical pattern for prospective areas lying outside the kitchens.

The Lower Jurassic Statfjord formation is also an important reservoir within the Statfjord field, with a stock tank oil initial in place (STOIIP) of over $1 \mathrm{Gbbl}$ of oil. This oil can also be correlated to the uppermost part of the Upper Jurassic Draupne formation source rock. However, the Statfjord formation is stratigraphically removed from the Upper Jurassic source rock and nowhere does the overlying fill-spill system at the Brent group level juxtapose across a fault with the Statfjord formation. Another explanation for hydrocarbon 


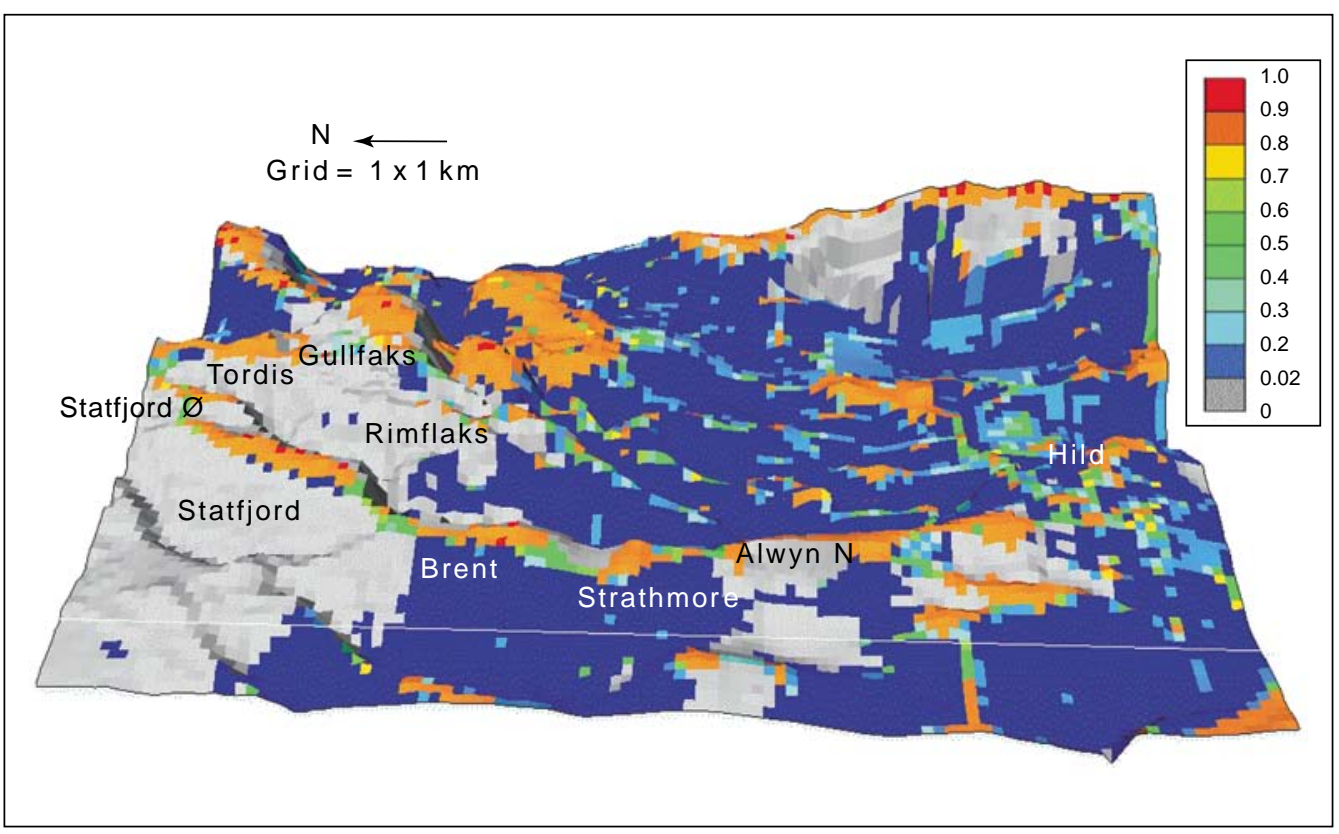

Figure 3

Present-day petroleum saturation in the Brent group. The structure is the present-day Top Brent group. Scale from saturation: 0\%-100\%. The major migration pathways and spill-fill routes can be seen.

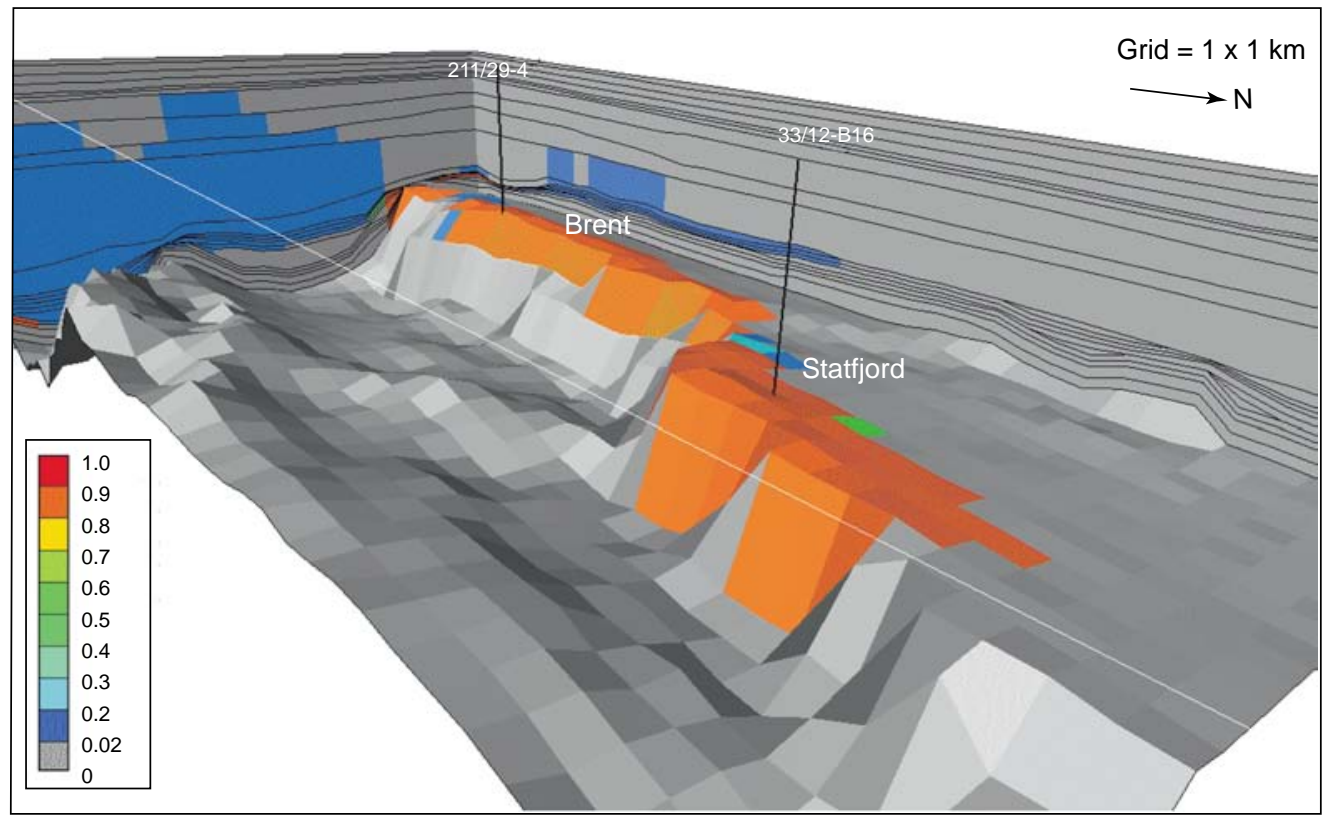

Figure 4

Present-day petroleum saturation in the Statfjord formation. The structure is the present-day Top Statfjord formation. Scale from saturation: $0 \%-100 \%$. The major migration pathways and spill-fill routes can be seen. 
delivery to the Statfjord formation is required. The origin of the hydrocarbons in the Statfjord formation must be explained so that the probability of charging other parts of the same fairway can be quantified.

Figure 4 illustrates the result of a model run to test the possibility for migration from the Upper Jurassic Draupne formation in the hanging wall basin, where it onlaps against the Statfjord formation in the footwall ridge which contains the Brent and Statfjord fields. A critical aspect of geology within this local basin is the distribution of Upper Jurassic Munin formation sandstones. These sandstones are quite common in the Tampen spur area and are penetrated in several wells within the hanging wall area of the Brent and Statfjord area. The Munin formation sandstones were shed from the Statfjord and Brent footwall block into the half graben directly to the east during periods when the crests of the tilted Jurassic fault blocks were sub-arealy exposed.

Petroleum is generated and expelled from the Draupne formation in the southern part of the hanging wall basin where the thermal maturity becomes sufficient. This petroleum is able to migrate laterally to the Munin formation sandstones, which results in secondary up-dip migration to the position of the onlap edge. Thereafter, cross-formational migration occurs where the Munin sandstones juxtapose against the Statfjord formation in the footwall block. Such juxtaposition is present in both Strathspey and Brent field locations. This structural configuration is the critical element to a successful migration pathway.
After migrating up dip to the west, the petroleum begins to migrate up dip to the north in the stratigraphically deeper reservoir. Charge to the Statfjord formation of the Statfjord field is achieved by further charging and eventual spill from the Brent field. The migration route is extremely focussed and again from the south.

The charge system for the Statfjord field therefore consists of two major spill-fill systems, one at the Brent group and one at the Statfjord formation level, with petroleum being delivered from the Draupne formation in three different basins. The Viking graben and the East Shetland basin charge the Brent group while the half graben to the east of the Strathspey to Brent fault block charges the Statfjord formation.

The multilayer, three-dimensional nature of the migration system is obvious, neither 2D sections nor ray-tracing techniques would provide a suitable method of assessment here since pressure-driven, downward migration followed by secondary migration in three different reservoir levels is required to explain the petroleum occurrences.

\section{GOR MODELING}

GOR prediction using 2D compositional modeling has been common within Statoil for several years. During this period we have used IFP's Temis 2D (Ungerer et al., 1990; Burrus et al., 1991) compositional modeling software. On the Norwegian shelf, we very often work on complex geological

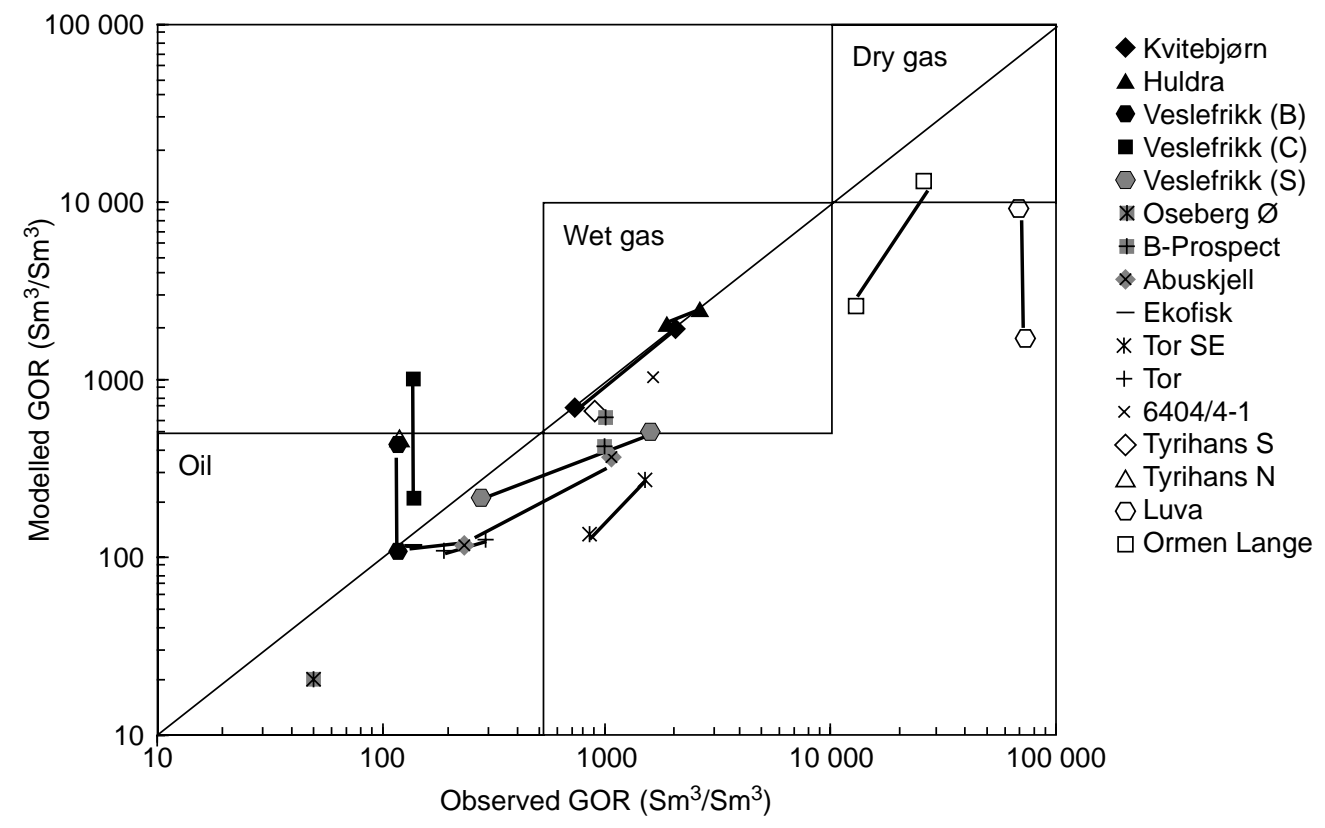

Figure 5

Observed versus predicted GOR. The predicted values are derived from 2D migration modeling. Solid lines show the range of uncertainty in certain cases. 
models with multiple source rock and reservoir units, and we also often have discoveries which allow us some degree of model calibration. It certainly is a benefit to be able to remove much of the geological uncertainty from our modeling due to the wealth of data available.

In our experience we see reasonable trends developing in our compositional models; that is, we observe a decreasing GOR with increasing distance from the kitchen area and we also observe an increasing GOR with depth (Hay et al., 2000).

Much of the compositional modeling carried out by Statoil has involved trying to understand or model fluids that have already been discovered. The reason is to increase our confidence in a certain sourcing model for analogous prospects, or to develop an understanding of the range of possible fluid compositional variations which could be encountered in segmented fields.

Figure 5 summarizes the experiences we have had comparing the observed GOR with the model-predicted GOR. The lines joining points represent variations or uncertainties in either or both the observed and modeled GOR. These models are the best we could do under normal operational working conditions.

As others have noted before (Vandenbroucke et al., 2000), we tend to underestimate the amount of gas and commonly model too low GOR values. The largest discrepancies are with very high GOR, dry gases where models have had up to $90 \%$ too little gas. However, in this high range GOR zone a very small volume of liquid has a very large effect upon the GOR. The boxes show approximate limits for some major fluid groups. Fortunately, the errors are often not significant enough to change gas into oil or vice versa.

Presently the use of compositional modeling to try to understand what we have found, and to understand the relative effects that geological model uncertainty may have on GOR, seems appropriate. However, true prediction of GOR in anything other than broad terms is difficult. We are challenged by geological uncertainty and confidence in the model parameters used to influence expelled fluid compositions.

\section{RESERVOIR QUALITY PREDICTION}

Historically, the prediction of reservoir porosity has involved the use of empirical porosity-depth curves and functions based upon them (Sclater and Christie, 1980). This is all very well, but is not really honoring the information that is available to us from the rocks themselves, especially at high temperatures.

Consider the Garn formation from the Halten bank (Fig. 6). We can find evidence for moderate quartz cementation (Ehrenberg, 1990; Walderhaug, 1996) which occurs at

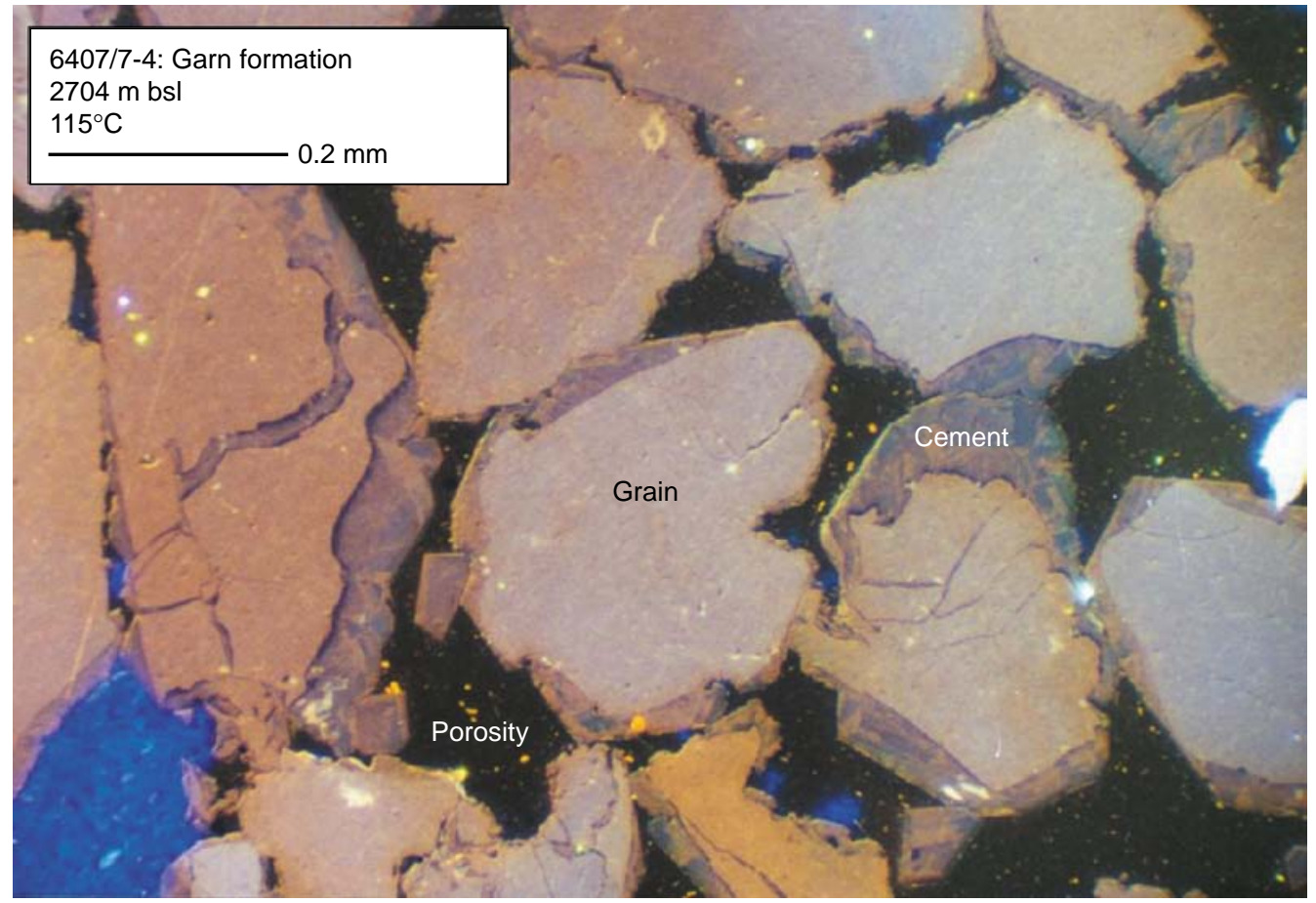

Figure 6

Thin section CL micrograph of the Garn formation from Haltenbanken showing evidence for moderate chemical compaction/cementation. 
temperatures above about $120^{\circ} \mathrm{C}$. When we look at sandstones, we see that two factors, mechanical compaction and chemical compaction, reduce the porosity. Mechanical compaction is a function of stress history whereas chemical compaction is a function of dissolution, diffusion and precipitation kinetics and therefore is responsive mostly to temperature and time (Walderhaug, 1996; Bjørkum et al., 1998). Observation shows that the quartz cement is derived from quartz dissolution along nearby, clay-rich stylolites-on the basin modeling scale the system is closed and we do not need to model long-distance transport of silica in aqueous solution. Observation also shows us that sandstone grain texture is important, with surface area $(\mathrm{Sa})$ having a great influence. Surface area can be quantified by point counting and calculated as a function of, amongst others, grain size and clay or micro-quartz grain coatings. A small surface area, due to large grains or extensive clay coatings, prevents quartz precipitation and therefore preserves porosity relative to the fine-grained, non-coated sediments shown in this micrograph.

To model porosity, Statoil has used a mechanical and chemical porosity reduction model with $1 \mathrm{D}$ thermal modeling, using geological's Exemplar or Fobos modeling software (Lander and Walderhaug, 1999). Mechanical compaction progresses until the kinetic-controlled quartz dissolution and precipitation start. Thereafter, the chemical compaction takes over with the quartz precipitation kinetics ultimately limiting the porosity reduction.

Our experiences with this form of porosity modeling in deep, high-temperature and high-pressure settings have been excellent. Figures $7 \mathrm{a}$ and $7 \mathrm{~b}$ show some grain-size- and surface-area-based porosity predictions against core plug porosity measurements. These predictions come from hightemperature reservoirs that are both normally pressured (Lavrans) and highly overpressured (Kristin). Not only is it possible to model the observed porosity but also the pointcounted volume of cement. We can therefore model the porosity evolution in accordance with the rock's stress and thermal history, irrespective of the reservoir fluid pressure.

Our experience shows that with the correct definition of grain size and surface area the model works in both the Brent group and the Garn formation (Walderhaug, 1996, 2000). It is most common to model a range of expected porosities based upon different grain size and surface area possibilities. In this way it is possible to provide a range of possible porosities likely to be encountered. The use of empirical porosity-depth curves to estimate reservoir porosity is no longer necessary, and our challenge is to predict the geographical distribution of factors such as clay coatings or micro-quartz overgrowths which could preserve high porosity under high-temperature conditions.

One key aspect of this prediction methodology is that porosity loss under chemical compaction is insensitive to changes in effective stress: this means that porosity loss is not stopped by the generation of high overpressure (Bjørkum and Nadeau, 1998). Neither, if the reservoir remains water-wet, will petroleum saturation significantly retard porosity loss since the quartz is locally sourced and able to diffuse through the irreducible pore water. The implications of this for modeling the petroleum system require further illustration.
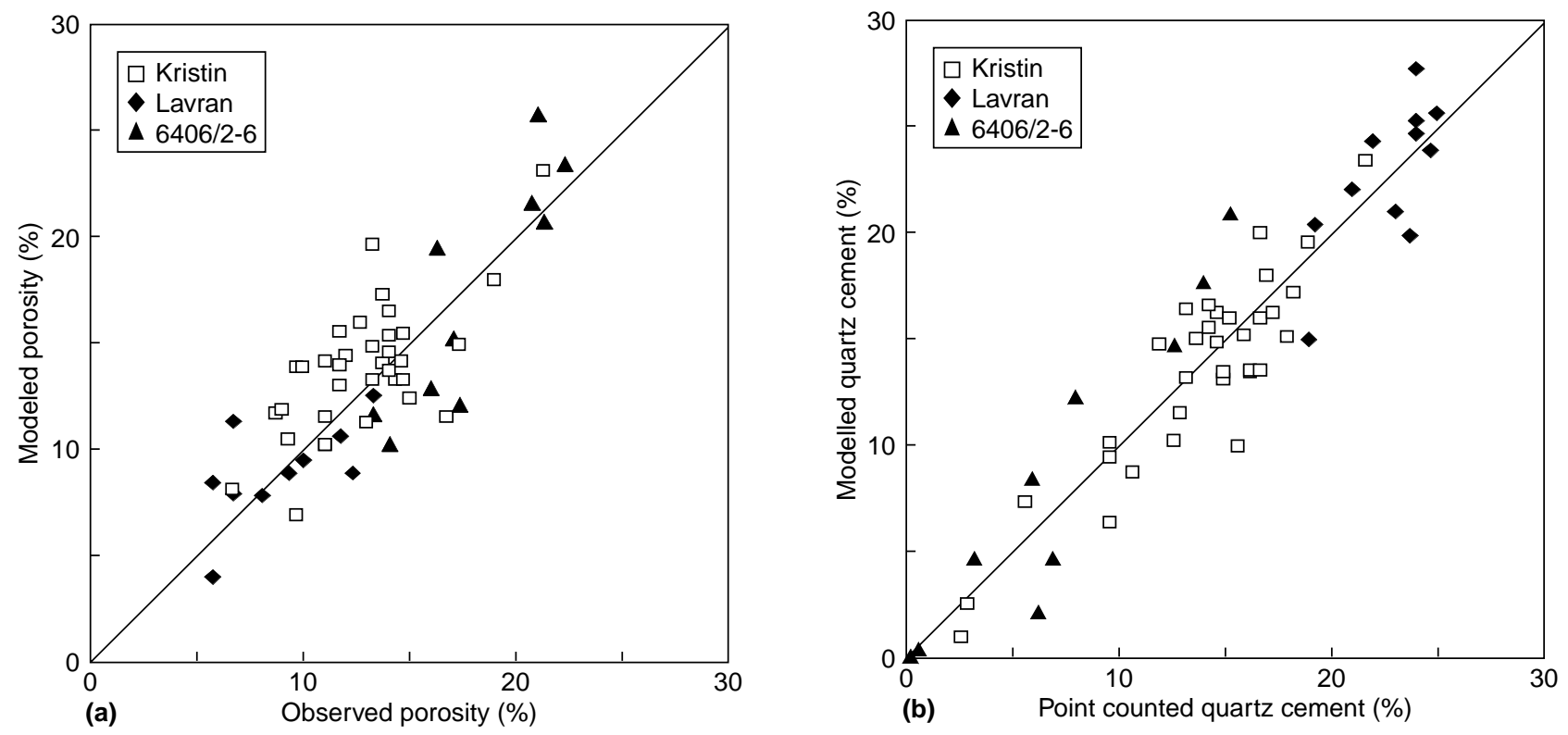

Figure 7

Observed versus predicted porosity (a) and cement volumes (b). The predicted values are derived from quantitative 1D modeling. 


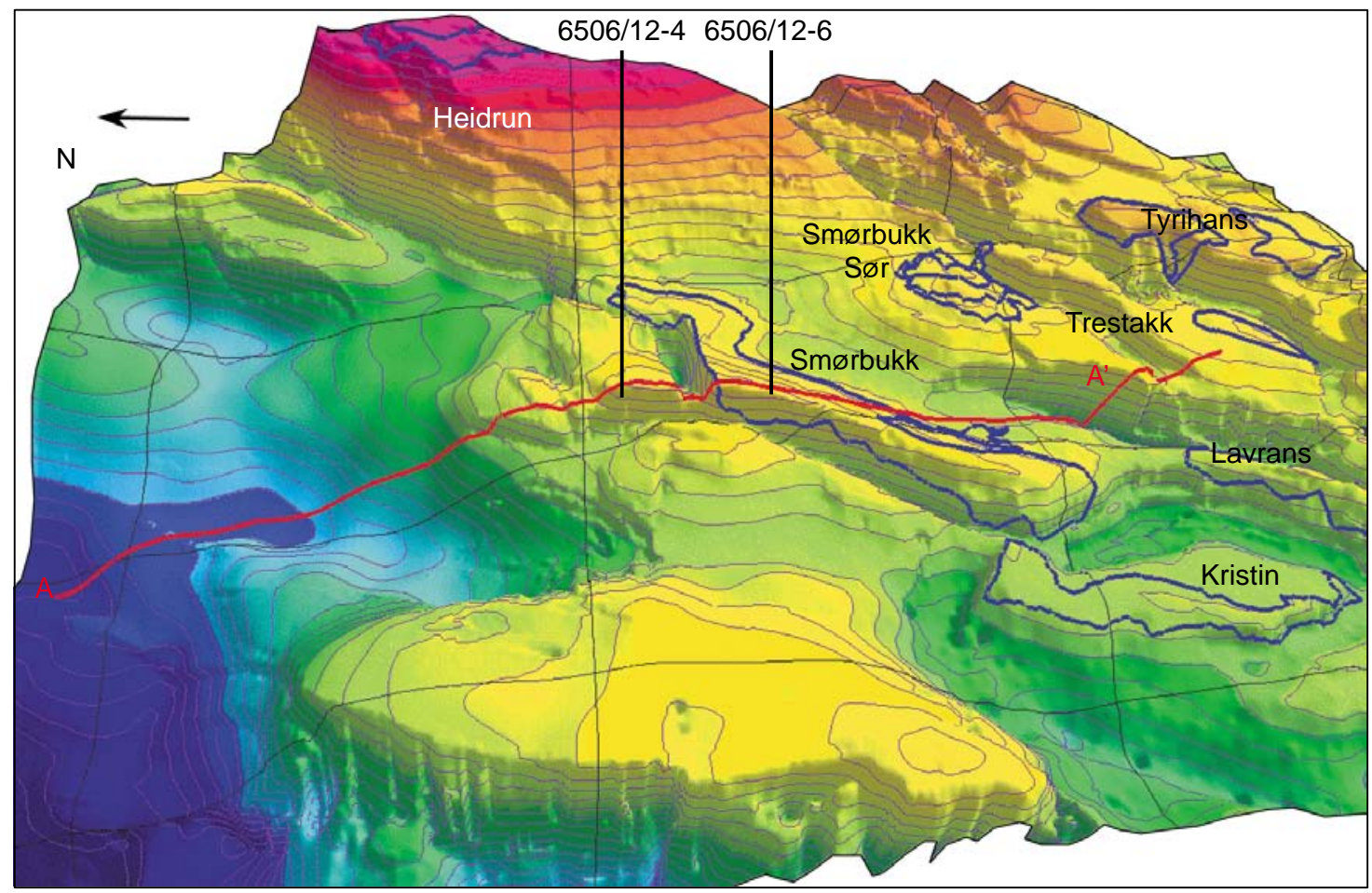

Figure 8

Present-day depth to the Top Garn formation in western Haltenbanken. The line A-A' was modeled to see the effect of chemical compaction on the petroleum system.

\section{OVERPRESSURE AND LEAKAGE MODELING IN THE WESTERN HALTEN BANK}

Studying the Garn formation of western Haltenbanken area can illustrate how we have improved our ability to model overpressure and trap leakage as a result of including chemical compaction in our quantitative modeling.

Figure 8 shows the western Haltenbanken area. The Smørbukk bounding fault runs from NE to SW across the area, separating the western, high-pressured zone containing the Kristin discovery from the eastern, normally-pressured zone containing amongst others the Smørbukk and Heidrun fields and the Lavrans discovery.

There are two wells marked. 6506/12-4 lies in the highpressure zone and has a present-day reservoir overpressure of some $26 \mathrm{MPa}$. The 6506/12-4 structure contains a residual hydrocarbon column. On the eastern side of the fault, Well 6506/12-6 lies within the Smørbukk field. Here the reservoir is normally pressured, in fact 2-MPa overpressured, and a significant hydrocarbon column is present.

In both wells the Garn formation is a well-sorted and clean, fine-grained quartzose sandstone which has experienced quartz cementation, being at $146^{\circ}$ and $150^{\circ} \mathrm{C}$ respectively in the two wells. Simulation was carried out using

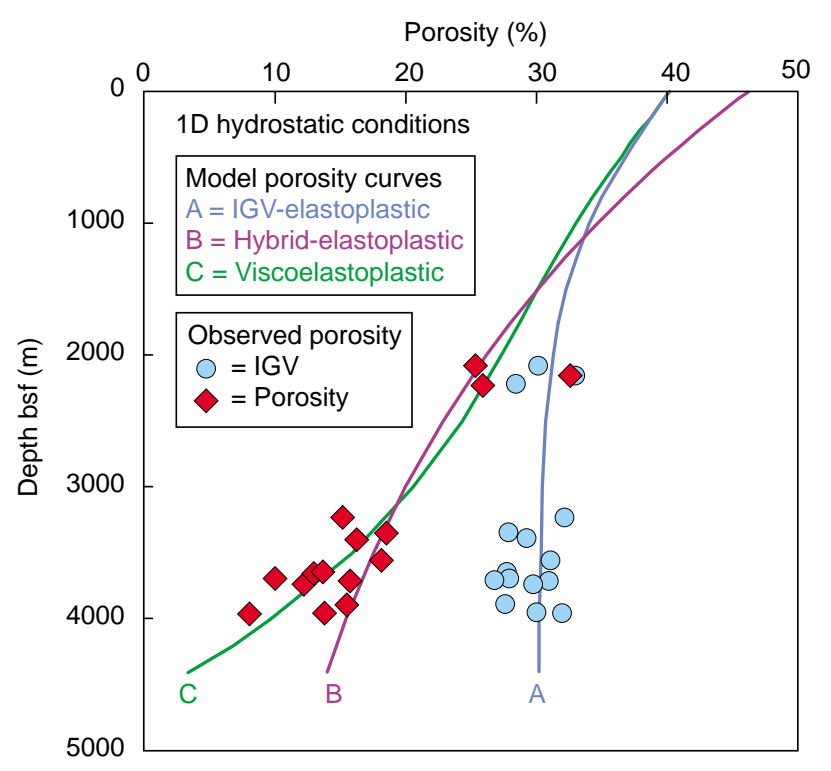

Figure 9

Model porosity curves. Curve A: intergranular volume; curve B: hybrid mechanical compaction; curve $\mathrm{C}$ : chemical compaction cement evolution. 
Temispack upon a 2D line, as shown in red, running from A to $\mathrm{A}^{\prime}$, close to the two wells with the aim of understanding the relative impact of chemical compaction.

In the model porosity evolution is described by a viscoelastoplastic function (Schneider et al., 1996; Schneider and Hay, 2001). This is in effect a combination of mechanical and chemical compaction up-scaled from grain-scale observations (Schneider and Hay, 2001).

Mechanical compaction is modeled as an effective stress function which one must define using the observed intergranular volume (Fig. 9), in the case of the Garn formation by the red curve (A). The observed porosity is predicted by the introduction of a kinetic function that models the progression of cementation (Curve C) which deviates from the defined intergranular volume and progresses in association with the time-temperature history.

Historically basin models have only been able to simulate mechanical compaction, for example by using an elastoplastic effective-stress law (Giles et al., 1998). Normally the modeler defines this law using a porosity-depth curve such as Curve B. This is a typical "Sclater and Christie" type, hydrostatic curve that attempts to match the evolution of both mechanical and chemical compaction in a single function. In some cases such a hybrid curve may provide a match to the observed presentday porosity but it does not necessarily capture the evolution of porosity when chemical compaction has been active.

Figure 10 illustrates the present-day porosity predictions using two compaction models, elastoplastic compaction and visco-elastoplastic compaction. The differences in the reservoir sections are obvious (Hay and Schneider, 2001).

Firstly, the present-day porosity under both high- and lowpressure settings is similar using the viscoelastoplastic model, low porosities are achieved even under very high overpressures (260 bar). Comparison with the elastoplastic model shows that the mechanical model results in unrealistically high porosities of $20 \%-25 \%$ at the highly overpressured
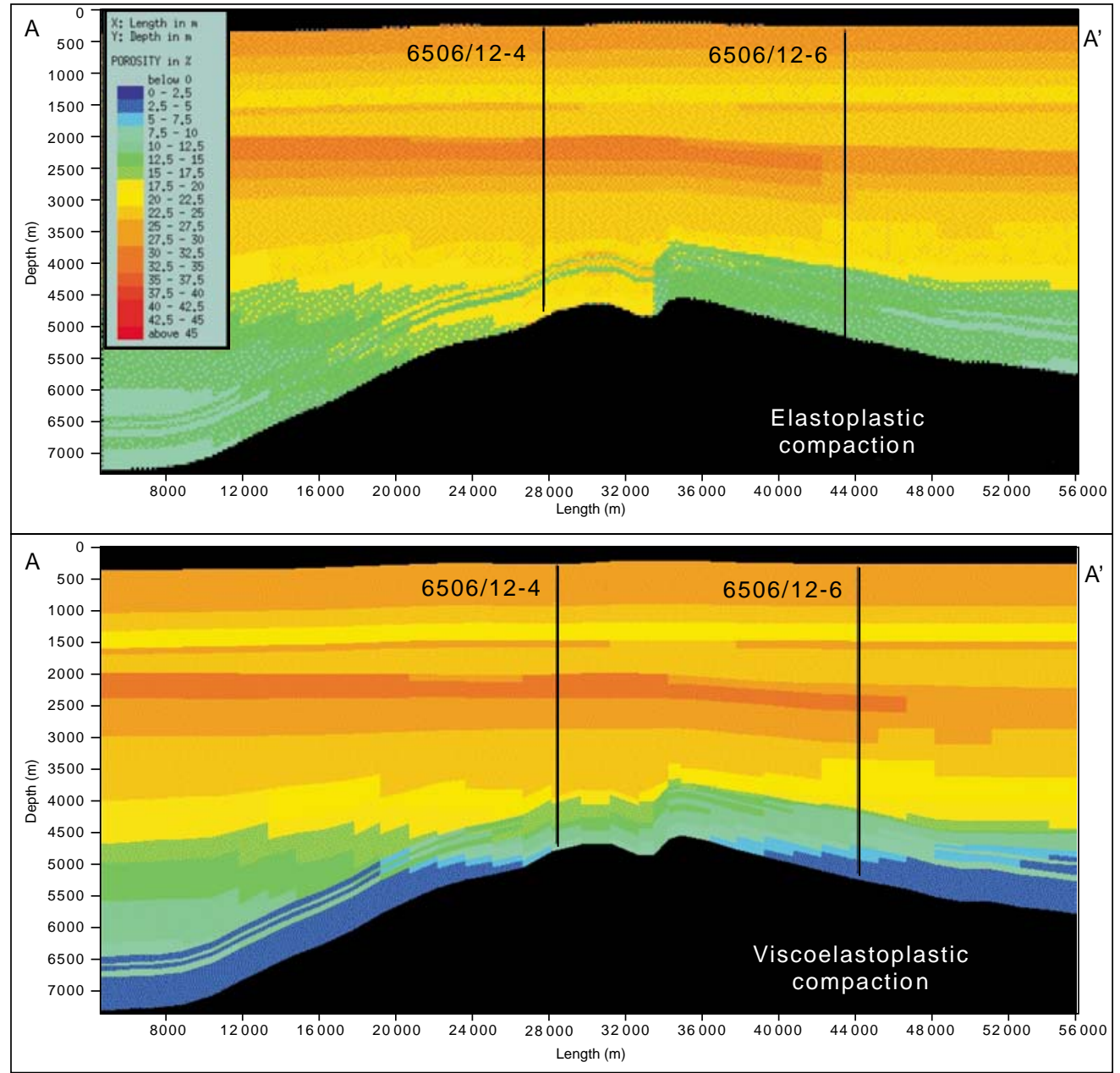

Figure 10

Modeled porosity using elastoplastic (mechanical) and viscoelastoplastic (mechanical and chemical) compaction models. 


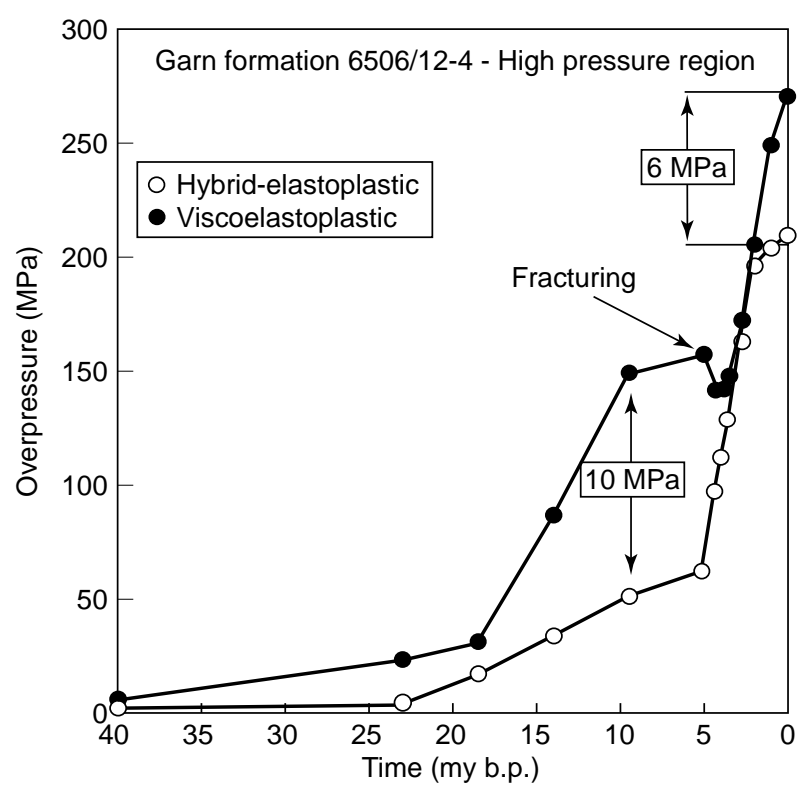

Figure 11

Predicted overpressure history for the Garn formation at Well 6506/12-4. Using elastoplastic (mechanical) and viscoelastoplastic (mechanical and chemical) compaction models. crest of the western half of the section in comparison to the observed $12 \%-20 \%$ seen in the well. In general, the elastoplastic model is unable to compact the reservoir rocks to the degree seen, even under hydrostatic conditions.

Such differences in porosity must have important implications for the fluid flow history. The starting point in both models was identical and the water occupying the nowcemented porosity must have been displaced. This will have to have gone somewhere.

This viscoelastoplastic model is a function of the absolute effective stress at a given time step, whereas the elastoplastic model is a function of the difference in the effective stress between consecutive time steps. This is significant and results in the viscoelastoplastic model there is always enough vertical stress to shorten the rock, even at high overpressures. Space for compaction is created by grain dissolution at stylolite seams, a chemical process relatively insensitive to pressure (Bjørkum, 1996).

The overpressure for the Garn formation at the 6506/12-4 well location in the high-pressure region using two compaction models is illustrated in Figure 11. During the late stages of the model, here from $25 \mathrm{My}$, the overpressure history shows significant differences. During this time period
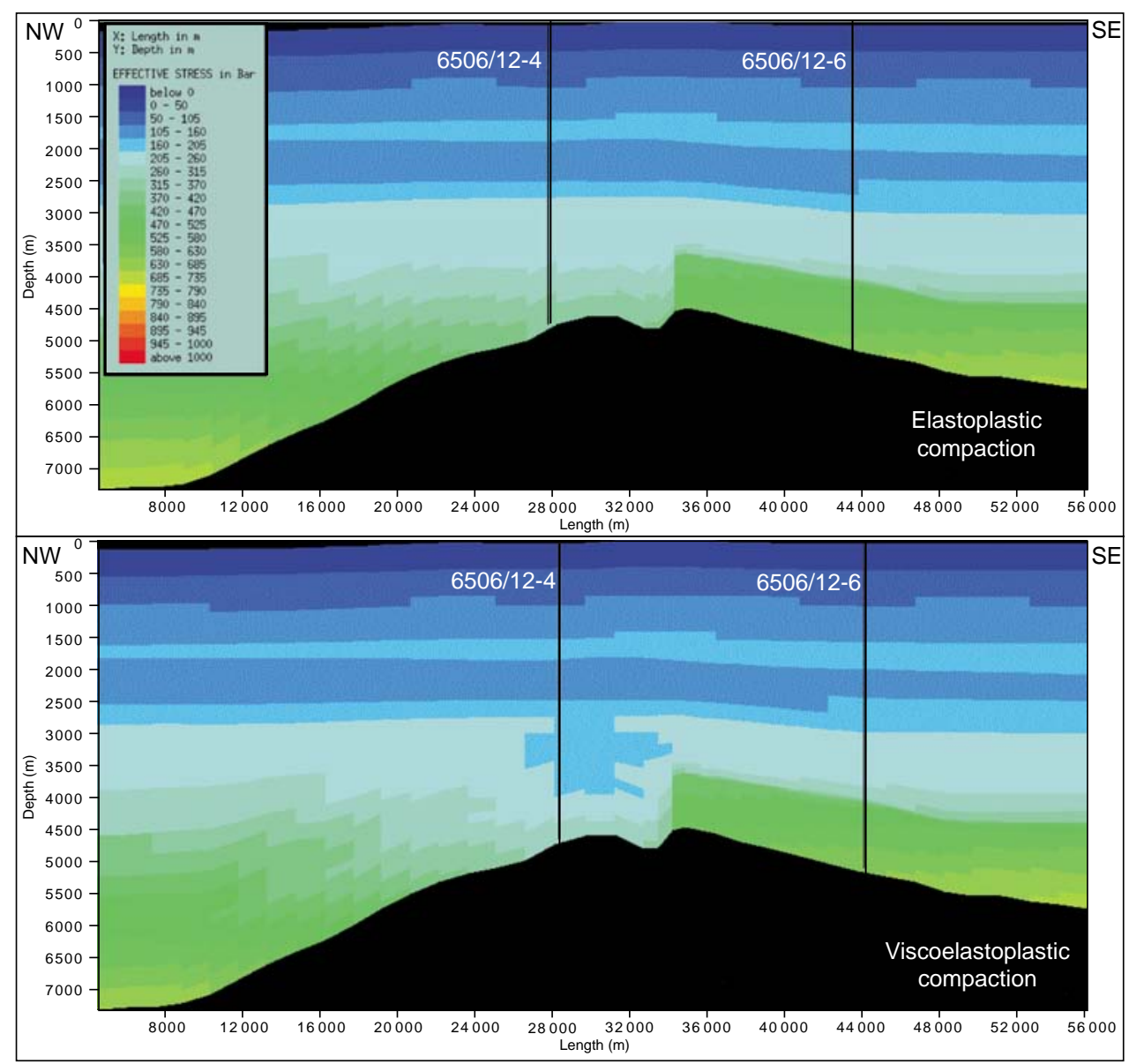

Figure 12

Modeled effective stress using elastoplastic (mechanical) and viscoelastoplastic (mechanical and chemical) compaction models. 
the elastoplastic model has ceased to compact whereas the viscoelastoplastic model continued compacting. Chemical compaction is seen to result in additional overpressure due to the expulsion of water from the pore space that is being filled by cement. When this cannot escape from the top of the structure as fast as it is delivered from below, the overpressure rises. Differences of up to $200 \%$ are observed over this period, with an absolute difference in overpressure as high as $10 \mathrm{MPa}$. Presently, some $6 \mathrm{MPa}$ or $28 \%$ of the observed overpressure can be attributed to chemical compaction.

It can be seen that just after $5 \mathrm{My}$, when the loading by the thick Plio-Pleistocene section has begun, the overpressure predicted by the viscoelastoplastic model reduces, whereas the overpressure predicted by the elastoplastic model steadily increases. This reduction in overpressure is due to a fracturing event that is predicted by the viscoelastoplastic model, resulting in fluid bleed-off above Well 6506/12-4. There is no fracturing seen when using the elastoplastic model.
The present-day distribution of effective stress is illustrated in Figure 12. A zone of decreased effective stress is simulated above the 6506/12-4 structure. This zone of reduced effective stress is caused by fluid bleed-off from the underlying reservoirs, with overpressure-induced fracturing of the impermeable top seal being the flow pathway. This difference in effective stress has a significant impact upon the distribution of petroleum.

Figure 13 shows the simulated petroleum saturation at both overpressured and normally pressured traps under the viscoelastoplastic and elastoplastic models. The differences are significant. In the viscoelastoplastic model the fracturation event at $5 \mathrm{My}$ resulted in the bleed-off of the hydrocarbon column previously held in the trap penetrated by Well $6506 / 12-4$. The residual saturation can be seen in the model and matches the well observations. This is not the case in the elastoplastic model that still maintains a column at this location that is known to have undergone a fatal leakage.

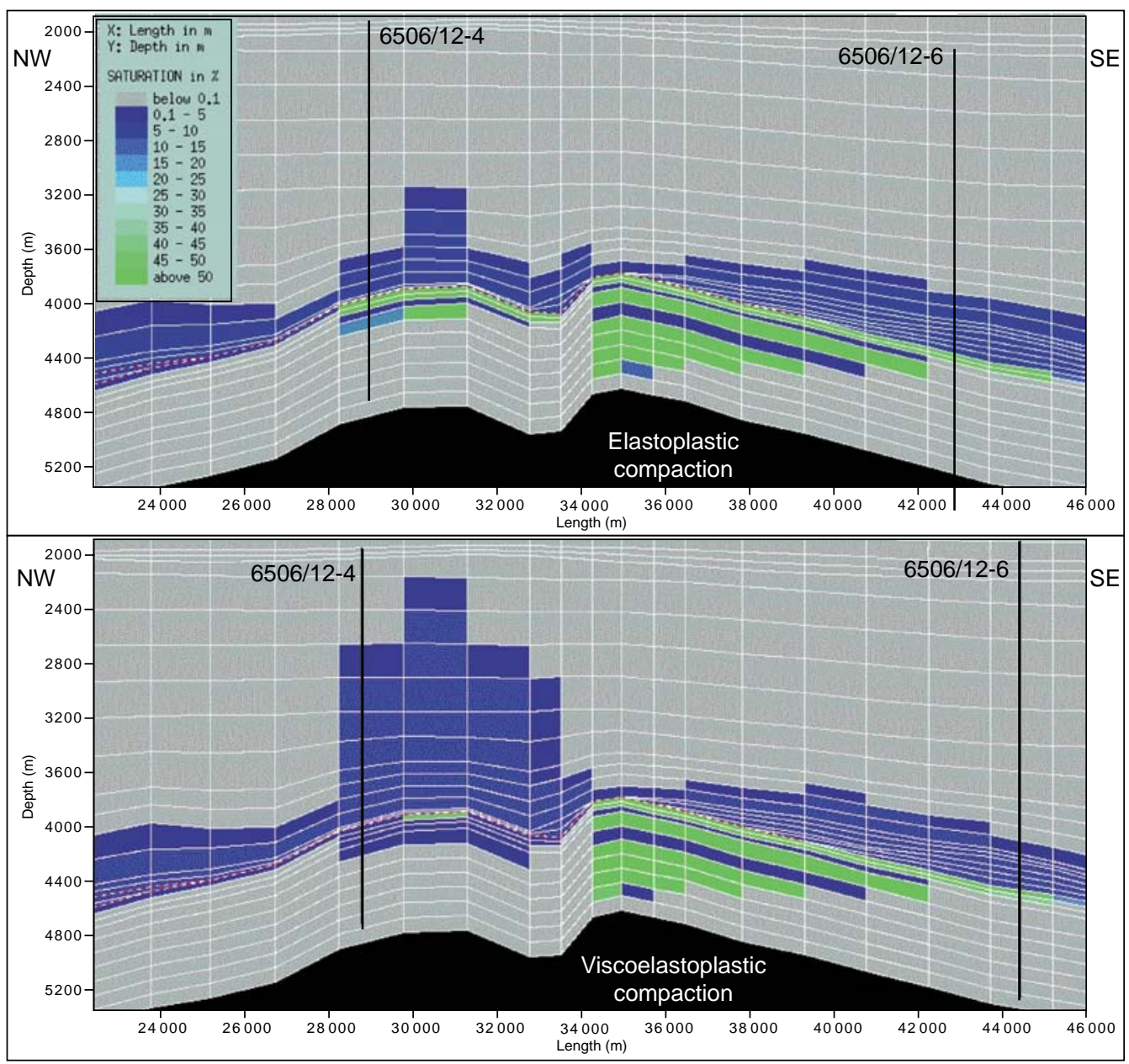

Figure 13

Modeled petroleum saturation using elastoplastic (mechanical) and viscoelastoplastic (mechanical and chemical) compaction models. 
Correspondingly, on the low-pressure side of the model the viscoelastoplastic compaction promotes a reduction in pore space when compared to the elastoplastic model. This results in a smaller trap pore volume and the volume of hydrocarbons that can be held in trap reduces. In this instance the trap experiences down-filling. At high temperatures chemical compaction therefore also promotes fill-spill. In the case shown here the porosities in both models for the normally pressured side are similar and the differences are only slight. They are however visible in the lowermost right-hand grid cell of the Smørbukk accumulation where the petroleum saturations are higher than in the viscoelastoplastic model.

\section{CONCLUSIONS}

Quantitative basin modeling aids our decision-making by providing us with an increased understanding of what we have already found, improved confidence in our decisionmaking, and a method to test the consequences of geological models. The value comes from a confident assessment of probability, which may either increase or decrease the value of a prospect.

In the North Sea, as anywhere, our critical risks depend upon where we are exploring, but we presently see longdistance migration to areas outside source kitchens or to satellite prospects as an area where we can increase our confidence with quantitative 3D modeling, as in the Statfjord area. Similarly with reservoir quality prediction where we are able to make reliable porosity estimations in deep, hightemperature and high-pressure areas by modeling what we actually see in the rocks. Through application of this principle, and the inclusion of a model for chemical compaction, we have improved our ability to model porosity, overpressure and trap leakage, with the result that we now have better confidence in our flow modeling results.

Presently the use of compositional modeling to try to understand the GOR we have found, and to understand the relative effects that geological model uncertainty may have on the GOR, seems appropriate. However prediction of GOR in anything other than broad terms is difficult. We are challenged by geological uncertainty and confidence in the model parameters used to influence expelled fluid compositions.

In certain situations a company can gain competitive advantage through making more confident, more realistic quantitative evaluations which allow the correct value decisions to be made. Although mature in an exploration sense, the North Sea is far from dead, in fact for basin modelers it is a place to add value.

\section{REFERENCES}

Bjørkum, P.A. (1996) How Important is Pressure in Causing Dissolution of Quartz in Sandstones? Journal of Sedimentary Research, 66, 147-154.
Bjørkum, P.A., Oelkers, E.H., Nadeau, P.H., Walderhaug, O. and Murphy, W. (1998) Porosity Prediction in Quartzose Sandstones as a Function of Time, Temperature, Depth, Stylolite Frequency and Hydrocarbon Saturation. AAPG Bulletin, 82, 637-648.

Bjørkum, P.A. and Nadeau, P.H. (1998) Temperature Controlled Porosity/Permeability Reduction, Fluid Migration, and Petroleum Exploration in Sedimentary Basins. Australian Petroleum and Exploration Association Journal, 38, 453-465.

Burrus, J., Kuhfuss, A., Doliguez, B. and Ungerer, P. (1991) Are Numerical Models Useful in Reconstructing the Migration of Hydrocarbons? A Discussion Based upon the North Viking Graben, in England, W.A. and Fleet, A.J. (eds.), Petroleum Migration, Geological Society London Special Publication, 59. 89-109.

Ehrenberg, S.J. (1990) Relationship Between Diagenesis and Reservoir Quality in Sandstones of the Garn Formation, Haltenbanken, Mid-Norwegian Continental Shelf. AAPG Bulletin, 74, 1538-1558.

Giles, M.R., Indrelid, S.L. and James, D.M.D. (1998) Compaction-The Great Unknown in Basin Modelling, in Duppenbecker, S.J. and Iliffe, J.E. (eds.), Basin Modelling: Practice and Progress, Geological Society London Special Publication, 141, 15-43.

Hay, S.J., Park, P.J. and Seim, K. (2000) Data Calibrated Migration Modeling in the Assessment of Brent Group Prospectivity: A Case Study from the Veslefrikk Area of the Norwegian North Viking Graben. Marine and Petroleum Geology, 17, 821-839.

Hay, S.J. and Schneider, F. (2001) Compaction Model for Quartzose Sandstones. Application to the Garn Formation, Haltenbanken, Mid-Norwegian Continental Shelf. Part II: Testing. 63rd EAGE Conference Abstracts, Amsterdam, O 027.

Johannesen, J., Hay, S.J., Milne, J.M., Jebsen, C. and Gunnesdal, S.C. (2000) The Petroleum System of the Statfjord Area, a 3DIntegrated Approach. 62nd EAGE Conference Abstracts, Glasgow, X 45.

Johannesen, J., Hay, S.J., Milne, J.M., Jebsen, C., Gunnesdal, S.C. and Vayssaire, A. (accepted) The Petroleum System of the Statfjord Area, Norwegian North Sea: Towards a 3D-Integrated Understanding in Late Life Exploration, Petroleum Geoscience.

Lander, R.H. and Walderhaug, O. (1999) Predicting Porosity Through Simulating Sandstone Compaction and Quartz Cementation. American Association of Petroleum Geologist Bulletin, 83, 433-449.

Roberts, J.D., Mathieson, A.S. and Hampson, J.M. (1987) Statfjord, in Spenser, A.M., Holter, E., Campbell, C.J., Hanslien, S.H., Nelson, P.H.H., Nysæther, E. and Ormaasen, E.G. (eds.), Geology of the Norwegian Oil and Gas Fields, Graham and Trotman, London, 319-340.

Schneider, F., Potdevin, J.L., Wolf, S. and Faille, I. (1996) Mechanical and Chemical Compaction Model for Sedimentary Basin Simulators. Tectonophysics, 263, 307-317.

Schneider, F. and Hay, S.J. (2001) Compaction Model for Quartzose Sandstones. Application to the Garn Formation, Haltenbanken, Mid-Norwegian Continental Shelf. Part I: Theory. 63rd EAGE Conference Abstracts, Amsterdam, O 026.

Schneider, F. and Hay, S.J. (in press) Compaction Model for Quartzose Sandstones. Application to the Garn Formation, Haltenbanken, Mid-Norwegian Continental Shelf. Marine and Petroleum Geology, 18/7, 833-849.

Schneider, F., Wolf, S., Faille, I. and Pot, D. (2000) A 3D Basin Model for Hydrocarbon Potential Evaluation: Application to Congo Offshore. Oil \& Gas Science and Technology, 55, 2-13. 
Schneider, F. and Wolf, S. (2000) Quantitative HC Potential Evaluation Using 3D Basin Modelling: Application to Franklin Structure, Central Graben, North Sea, UK. Marine and Petroleum Geology, 17, 841-856.

Sclater, J.G. and Christie, P.A.F. (1980) Continental Stretching: An Explanation of the Post-Mid Cretaceous Subsidence of the Central North Sea. Journal of Geophysical Research, 85, 37113739.

Ungerer, P., Burrus, J., Doliguez, B., Chénet, P.Y. and Bessis, F. (1990) Basin Evaluation by Integrated Two-Dimensional Modelling of Heat Transfer, Fluid Flow, Hydrocarbon Generation, and Migration. AAPG Bulletin, 74, 309-335.
Walderhaug, O. (1996) Kinetic Modeling of Quartz Cementation and Porosity Loss in Deeply Buried Sandstone Reservoirs. AAPG Bulletin, 84, 731-745.

Walderhaug, O. (2000) Modeling Quartz Cementation and Porosity in Middle Jurassic Brent Group Sandstones of the Kvitebjørn Field, Northern North Sea. AAPG Bulletin, 84, 13251339.

Vandenbroucke, M., Behar, F. and Rudkiewicz, J.L. (2000) Kinetic Modeling of Petroleum Formation and Cracking: Implications from the High Pressure/High Temperature Elgin Field (UK, North Sea). Organic Geochemistry, 30, 1105-1125.

Final manuscript received in November 2001 